\title{
A high-pressure granulite facies complex in north-west Payers Land, East Greenland fold belt
}

\author{
HANS CHRISTIAN LARSEN
}

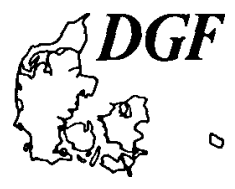

\begin{abstract}
Larsen, H. C.: A high-pressure granulite facies complex in north-west Payers Land, East Greenland fold belt. Bull. geol. Soc. Denmark, vol. 29, pp. 161-174, Copenhagen, January 19th, 1981. https://cioi.org/10.37570/bgsci-1980-29-11

Aeromagnetic, geological and geochemical data demonstrate the presence of a high-pressure, granu-lite-facies gneiss complex about $400 \mathrm{~km}^{2}$ in area within a previously almost unexplored nunatak region between latitudes $74^{\circ} 30$ and $75^{\circ} \mathrm{N}$ in northern East Greenland. The gneiss complex is surrounded and in part overthrust by supracrustal rocks of very high amphibolite facies, including gamet-clinopyroxene rocks of eclogitic affinity. A magnetically anomalous area is related to exposures of granulite facies rocks, whereas the surrounding supracrustals give rise to a magnetic smooth zone. Several, independent sets of observations indicate that the granulite facies metamorphism and the high amphibolite facies metamor-phism were related to the same metamorphic event. Maximum temperatures of about $740^{\circ} \mathrm{C}$ and maximum pressures of about $12.5 \mathrm{~kb}$ were reached (kyanite formation) later decreasing to about $10 \mathrm{~kb}$ (sillimanite formation). Comparisons with other parts of the East Greenland fold belt suggest a probable Archaean origin for the central gneiss complex and an early or middle Proterozoic age for the granulite and amphibolite facies metamorphism. There are no indications of Caledonian metamorphic events, in contrast to the previously assumed Caledonian origin for the area.
\end{abstract}

Hans Christian Larsen, Geological Survey of Greenland, Øster Voldgade 10, DK-1350 Copenhagen K, Denmark, September 2nd, 1980.

\section{Introduction}

The area studied comprise about $850 \mathrm{~km}^{2}$ of north-west Payers Land between latitudes $74^{\circ} 30^{\prime}$ and $75^{\circ} \mathrm{N}$ within the nunatak region in North-East Greenland (fig. 1). With the exception of very limited observations made from aircraft (Haller 1970), and brief observations of parts of the area by Mittelholzer (1941) and Leedal (1952), the area was virtually unexplored prior to the investigations undertaken in 1974 and reported here. The only available map (sheet 74Ø2 scale 1:250.000 Geodetic Institute, Copenhagen) is of poor quality, although the most striking errors have been corrected on regional geological maps by Koch \& Haller (1971). No vertical aerial photographs of the area exist.

The flat-topped nunataks form a peneplain at a level of $1300-1600 \mathrm{~m}$. The highest point at 1800 $\mathrm{m}$ is a prominent mountain formed by a very large boudin of meta-basic rocks, which was clearly relatively resistant to erosion. Exposures are poor or lacking on the flat-topped plateaus, whereas the steep valley slopes provide good exposures accessable from the glaciers.

The area is situated well within the East
Greenland Caledonian fold belt (see e.g. Haller 1970, p. 55 and Haller 1971). The regional geological map of Koch \& Haller (1971) indicates the presence of dominantly synorogenic granites, migmatites, amphibolites and biotite schists, all of which are presumed to be of Caledonian age. Mittelholzer (1941) and Leedal (1952) reported the occurrence of hornblende gneisses, referred to as "basement gneisses", garnet amphibolites and semi-pelitic schists.

To the north and west, the area is bounded by the Inland Ice, and to the east by some major faults or high angle thrusts against the migmatitic zone of the Tyroler Fjord area (fig. 2 and Leedal, 1952). To the south-east the rocks of the area are faulted against quartzitic and phyllitic strata, overlain by virtually unmetamorphosed sediments of the Late Precambrian upper Eleonore Bay Group (fig. 2, Mittelholzer, 1941, Leedal, 1952, Haller, 1970, Koch and Haller, 1971).

The presence of high amplitude/high frequency magnetic anomalies within north-west Payers Land was demonstrated during an extensive airborne geophysical reconnaissance survey carried out in East Greenland in 1973 and 1974 between latitudes $70^{\circ} \mathrm{N}$ and $76^{\circ} \mathrm{N}$ (Nielsen and Larsen 


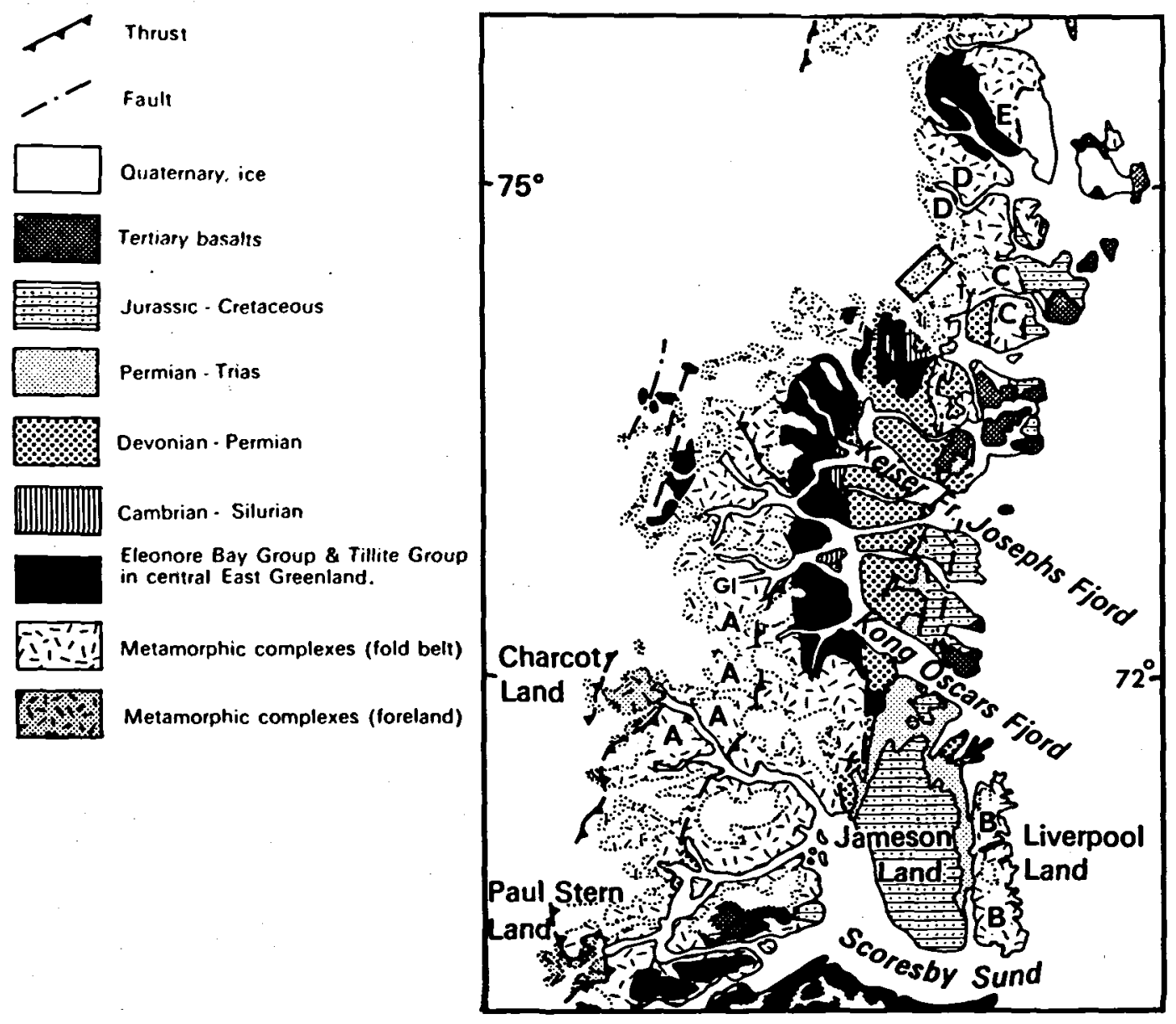

Fig. 1. Major geological units of North-East Greenland. Survey area (Payers Land) indicated by a rectangle. Ty: Tyroler Fjord. Gletscherland (G1) and Payers Land are the main magnetically anomalous areas within the otherwise magnetic smooth relief of the East Greenland Caledonides. Exceptions are minor anomaly populations lettered $\mathrm{A}$ to $\mathrm{E}$ and discussed in the text as being possible Archaean to early Proterozoic crystalline units. Regional geology adapted from Higgins and Phillips (1979).

1974, Nielsen and Steenfelt 1975, Larsen 1975, 1977). The total body of magnetic data reveals, that major parts of the Caledonian fold belt in East Greenland have a very low degree of magnetization. However, the monotonous low magnetic relief is interrupted by two anomalous areas, one in north-west Payers Land, and the second in Gletscherland between latitudes $72^{\circ} 30^{\prime} \mathrm{N}$ and $73^{\circ} \mathrm{N}$ (fig. 1, Larsen 1975, 1977). Total field anomalies from a few hundred up to more than two thousand gammas in amplitude characterise these areas.

In 1974, 12 days of ground geophysical and geological work were carried out within north-west Payers Land. Transportation to and from the area and placing of some food depots was made by helicopter, but within the area traverses were made by ski or on foot.

Field work concentrated on magnetic (susceptibility readings only) and geological profiling with the aim of explaining the anomaly pattern in geological terms. Taken together with subsequent laboratory work on petrography and geochemistry, a rather simple model emerged. The magnetically anomalous area was found to consist of a general highly magnetized central basement dome made up of hypersthene gneisses and more basic enderbitic rocks. This was surrounded by 
much less magnetized sillimanite bearing supracrustal rocks. The nature of the rocks encountered has only a modest resemblance to the rock types depicted on the geological map by Koch and Haller (1971), and contradicts their suggested Caledonian origin.

\section{Magnetic data}

Data from the airborne magnetic survey are shown in fig. 2. Spacing between flight tracks was about $2.5 \mathrm{~km}$ and the flight altitude $300-400 \mathrm{~m}$ above the plateau level formed by most of the nunataks. Although part of the anomaly pattern is clearly related to the presence of the deep valleys cut into the main plateau, the geological information in the anomaly map is still clear.

The magnetic field was measured by a proton precession magnetometer (Geometrics G803) installed in a Britten-Norman Islander with the sensor in a tail-stinger. All tracks were flown during one flight which took place within a period of low diurnal activity. The latter was controlled by a ground station in the base camp about 150 $\mathrm{km}$ to the south of the survey area.

The digital recordings (paper tape) of the magnetic field in the aircraft and in the base camp were correlated by quartz clock. Flight altitude was controlled by manual readings of the aircraft altimeter (barometric altitude).

Navigation was by visual observations and continuous photography along flight-tracks. The uncertainty in positioning arising from the rather poor map base was not found to seriously distort the anomaly pattern.

The magnetic data (fig. 2) comprises a central disturbed area with fairly sharp transitions towards the north-east and south-west into areas of gentle and smooth magnetic gradients. From aeromagnetic data in adjacent areas these gradients are known to flatten within rather short distances.

Susceptibility measurements made during field work and total magnetic moment measurements subsequently made in the laboratory. show a bimodal distribution in close agreement with the main trend of the total magnetic field data (fig. 2). Within the smooth magnetic areas, all samples show resulting magnetization from $10^{-4}$ to $10^{-5}$ EMU (or lower). By contrast, samples from the central magnetic disturbed area frequently show resulting magnetization between $10^{-3}$ to $10^{-2}$ EMU (or higher).

Due to the limited resolution of the magnetic data across the widely spaced tracks and the reconnaissance nature of the field work, no attempt is made to precisely review or model the individual anomalies found within the central disturbed area. However, a few comments on some very pronounced and easily explained anomalies are given in fig. 2.

\section{Geological observations}

Two major types of rock unit exist within the area investigated. These are a gneiss dome corresponding to the magnetically disturbed area and a supracrustal rock sequence corresponding to the magnetically smooth zone (fig. 2).

\section{Central gneiss complex}

The dome-like exposure of the central complex covers an area of about $400 \mathrm{~km}^{2}$ and forms an open NNE-SSW trending anticlinal structure (as also shown by Haller 1970). Mittelholzer (1941) and Leedal (1952) distinguished the gneisses exposed adjacent to the Inland Ice from the migmatites and granites of the Tyroler Fjord area (fig. 2); they termed them "basement gneiss" or "basement hornblende gneiss", an interpretation supported by the new observations by the writer. Koch and Haller (1971), however, interpreted the gneisses as synorogenic granites and migmatites formed at a deep level during the Caledonian orogeny.

The gneiss complex can be roughly divided into a central area of medium to fine grained nebulitic and agmatitic, light coloured biotite-hypersthene gneisses, and marginal areas of strongly sheared granulites (s.s.). The central gneisses typically have a leuco-granitic to granodioritic composition (fig. 3, table 1; sample 132924 and 132921). Feldspar and quartz dominate, with mafic minerals (biotite, hypersthene, magnetite, ilmenite and rare relicts of garnet) forming up to $10 \%$ of the rock. Partly rounded grains of zircon, up to $1 \mathrm{~mm}$ in size, and small grains of apatite, occur as accessory minerals. A striking feature is the invariable absence of twinning within the feldspars, 


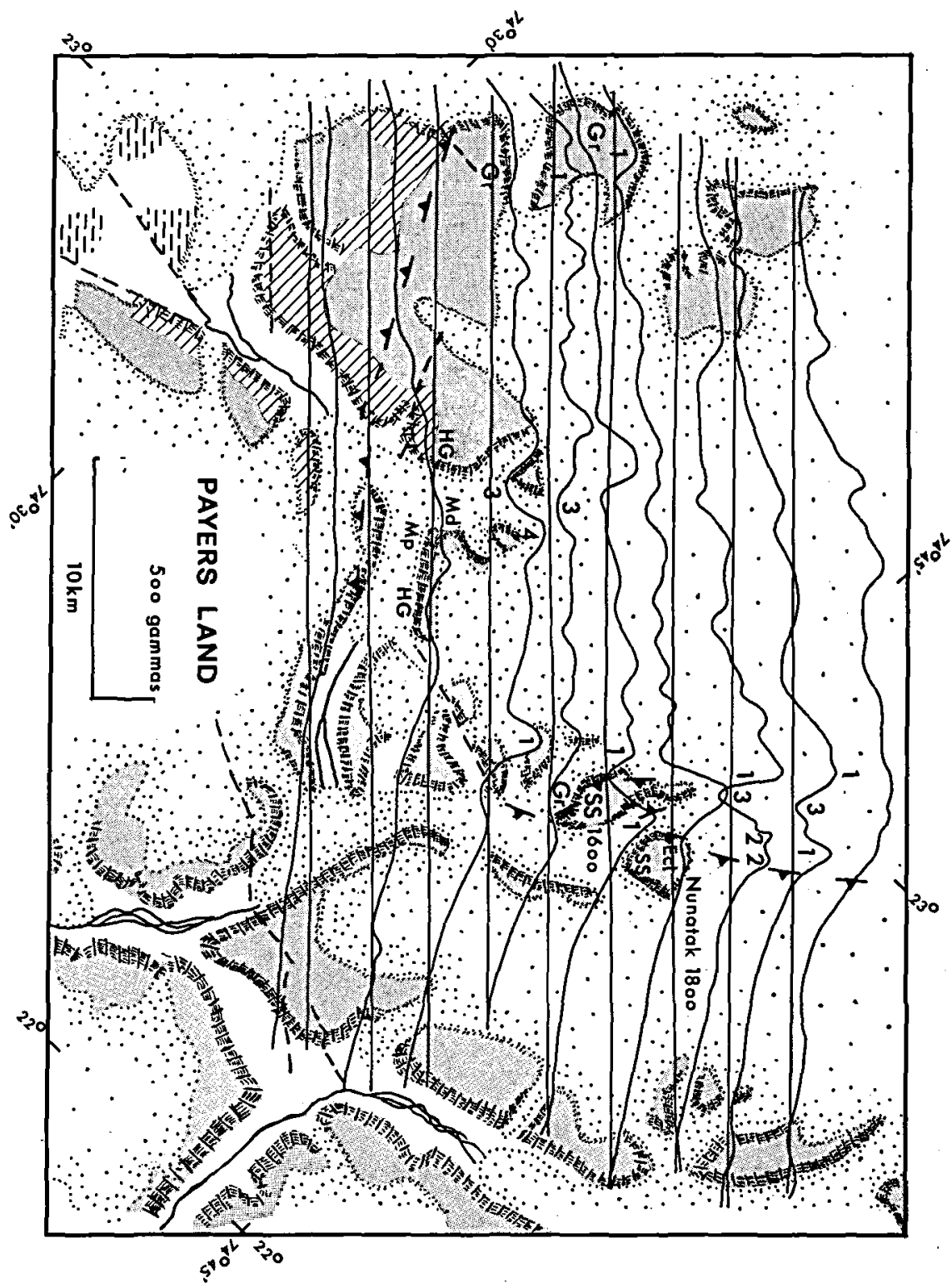

Fig. 2. Total magnetic field data from north-west Payers Land shown along flight-tracks and simplified morphology and geology. Dotted areas: Inland Ice, local icecaps or glaciers. Shaded areas: ice free plateaues. Heavy dashed line with arrows: Boundary between central magnetic disturbed area and the surrounding magnetic smooth zone. Observed at Nunatak 1600 to be a thrust zone. See text for discussion. Dashed lines: Selected faults from Koch and Haller (1971). Horizontal hatching: Nonmetamorphic late Precambrian Eleonore Bay Group and Cambro-Ordovician sediments. From Koch and Haller (1971). Cross-hatching: Low-grade quartzites and phyllites. From Koch and Haller (1971). Ecl: Eclogite-like metabasic body (sample 132931). SS: Sillimanite schist. Gr: Granulites (s.s.) HG: Hypersthene gneiss. Md: Metadolerite (sample 132926). Mp: Meta-pyroxenite. Magnetic anomaly explanation: (1) Anomalies caused by the presence of marginal granulites (s.s.); (2) the small anomalies superimposed on top of the major anomaly arising from the granulites, relates to the presence of a major eclogite-like metabasic body (Ecl); (3) magnetic lows caused by deep valleys and their extension below the Inland Ice; (4) anomaly arising from a metadolerite (sample 132926). See text for further discussion of anomalies and geology. Flight-line level: 54000 gammas; regional gradient not removed. 
TABLE 1

\begin{tabular}{|c|c|c|c|c|c|c|c|c|c|c|}
\hline & cer & otral gne & iss comp & Majo & and $\operatorname{tra}$ & $\begin{array}{l}\text { e elemer } \\
\text { ranulit }\end{array}$ & $\begin{array}{c}n t \\
\vdots \\
\text { es }\end{array}$ & emistry & sts & semi-eclogite \\
\hline Sample & no.132921 & 132924 & 132925 & 132926 & 132904 & 132906 & 132918 & 132917 & 132929 & 132931 \\
\hline $\mathrm{SiO}_{2}$ & 70.49 & 73.30 & 44.33 & 47.38 & 59.89 & 69.49 & 51.86 & 58.78 & 60.47 & 50.84 \\
\hline $\mathrm{TiO}_{2}$ & 0.25 & 0.22 & 1.54 & 1.90 & 0.71 & 0.27 & 1.48 & 0.96 & 0.97 & 1.09 \\
\hline $\mathrm{Al}_{2} \mathrm{O}_{3}$ & 16.28 & 14.60 & 9.23 & 13.59 & 16.78 & 15.73 & 19.16 & 19.39 & 19.52 & 13.54 \\
\hline $\mathrm{Fe}_{2} \mathrm{O}_{3}$ & 0.13 & 0.20 & 3.39 & 6.46 & 1.94 & 1.09 & 2.81 & 5.06 & 0.69 & 3.07 \\
\hline $\mathrm{FeO}$ & 1.67 & 1.49 & 7.25 & 12.03 & 3.39 & 1.51 & 5.11 & 5.04 & 7.96 & 11.92 \\
\hline MnO & 0.05 & 0.03 & 0.14 & 0.30 & 0.09 & 0.09 & 0.11 & 0.51 & 0.26 & 0.28 \\
\hline $\mathrm{MgO}$ & 0.73 & 0.61 & 15.47 & 5.42 & 2.92 & 0.49 & 3.57 & 3.01 & 3.51 & 7.09 \\
\hline $\mathrm{CaO}$ & 3.74 & 3.20 & 12.68 & 10.26 & 5.09 & 2.39 & 7.64 & 1.39 & 1.19 & 11.85 \\
\hline $\mathrm{Na}_{2} \mathrm{O}$ & 4.98 & 4.52 & 1.32 & 2.46 & 4.08 & 3.46 & 4.82 & 0.88 & 0.78 & 0.93 \\
\hline $\mathrm{K}_{2} \mathrm{O}$ & 0.66 & 0.81 & 0.98 & 0.23 & 3.13 & 4.56 & 0.88 & 4.51 & 3.53 & 0.03 \\
\hline $\mathrm{P}_{2} \mathrm{O}_{5}$ & 0.03 & 0.00 & 0.68 & 0.29 & 0.46 & 0.09 & 0.73 & 0.11 & 0.14 & 0.04 \\
\hline LoI & 0.42 & 0.34 & 2.21 & 0.18 & 0.71 & 0.29 & 1.06 & 0.60 & 1.03 & 0.20 \\
\hline Tot & 99.43 & 99.32 & 99.22 & 100.50 & 99.19 & 99.46 & 99.23 & 100.24 & 100.05 & 100.68 \\
\hline $\mathrm{Rb}$ & $<2$ & 3 & & $<2$ & 50 & & 5 & & & \\
\hline $5 r$ & 340 & 310 & & 100 & 1300 & & 1300 & & & \\
\hline $\mathrm{Rb} / \mathrm{Sr}$ & $<0.01$ & 0.01 & & $<0.02$ & 0.04 & & 0.004 & & & \\
\hline$K / R b$ & $>2700$ & 2241 & & $>950$ & 519 & & 1461 & & & \\
\hline
\end{tabular}

$2 X$-ray flourescence

which in most cases show a strong perthitic or antiperthitic structure.

Two different types of metabasic rocks occur as well-defined major boudins within the grey gneiss. One type is a coarse grained, ultrabasic meta-pyroxenite, rich in magnesium and calcium and low in silica (table 1, sample 132925). The second type is a medium grained, iron-rich, garnet, clinopyroxene, antiperthite, magnetite metadolerite of quartz-tholeiitic composition (table 1 and 2, fig. 3, sample 132926). The mineral paragenesis of the second type is almost identical to that of metabasic and pyrobolitic rocks from well known granulite facies terrains such as Varberg ("dark granulite", Qensel 1952) and Adirondack ("Woolen Mill Gabbro", Buddington 1939, Waard 1967).

The mineral assemblages observed within the central gneiss complex developed during regional granulite facies metamorphism. Furthermore, the metadolerite paragenesis indicates conditions of high pressure clinopyroxene-almandine subfacies (9 $\mathrm{kb}$ at $750^{\circ} \mathrm{C}$, Waard 1965 , Winkler 1967). Microprobe data (table 3, sample 132926) reveal a zonation of the clinopyroxene with a dominant, and constant, diopside content and strongly decreasing ratio between the jadeite and
CaTs-molecule content from core to rim. This can be taken to indicate an increasing temparature/pressure ratio during the metamorphic formation of clinopyroxene (Green and Ringwood, 1967). A similar trend can be shown in the overlying supracrustals (see below).

As seen in many other granulite facies terrains, the central gneiss complex shows pronounced depletion in potassium and rubidium (table 1). This is especially well exemplified by the hypersthene gneisses, which have less than one percent of potassium and only a few ppm rubidium (table 1 , sample 132921 and 132924). The very high $\mathrm{K} / \mathrm{Rb}$ ratio $(>2000$, table 1$)$ compared to the normal range for granitoid rocks (150-300, Taylor 1965) indicates that rubidium suffered the most serious depletion.

Considerable depletion in rubidium also seems to have taken place within the marginal granulites (see below), whereas their content of potassium seem only little affected (table 1, sample 132904 and 132918).

The granulites (s.s.) occupying the marginal parts of the gneiss dome were investigated at the southern cliff face of nunatak 1600 where an approximately $300 \mathrm{~m}$ high, well exposed section can be reached from the nearby glacier (fig. 4). The 

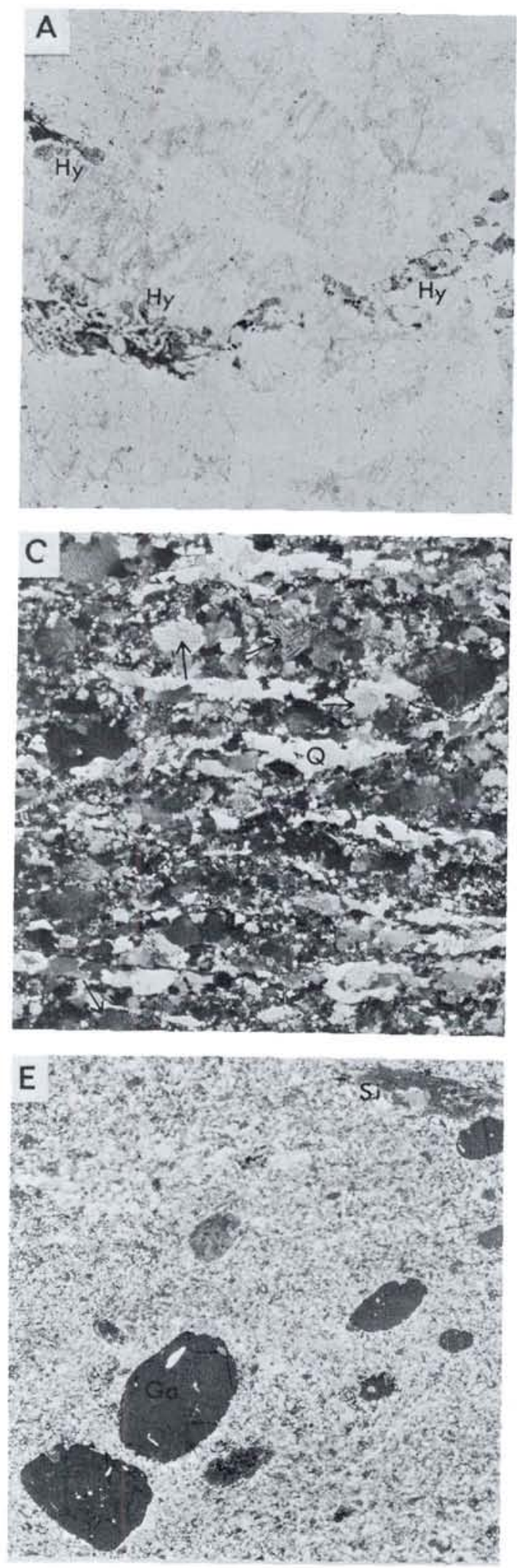

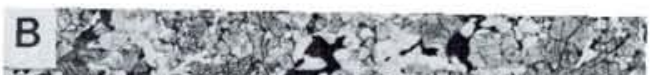

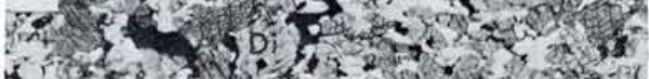

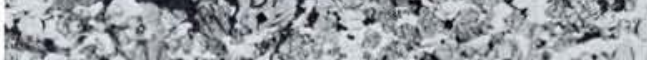

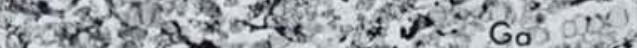

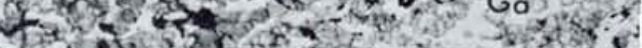

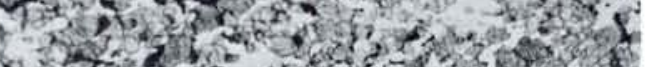

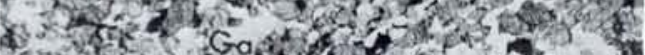

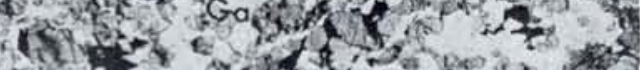

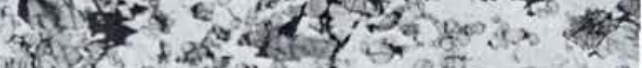

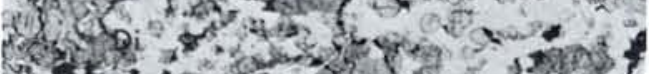

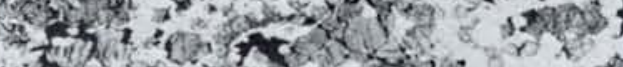
Hos $x+70$.

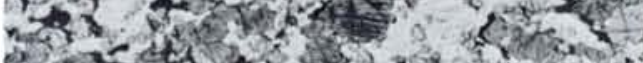

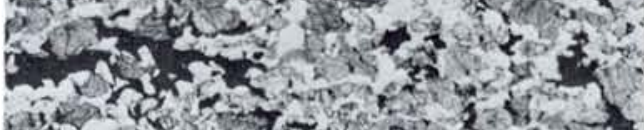
336. 4.
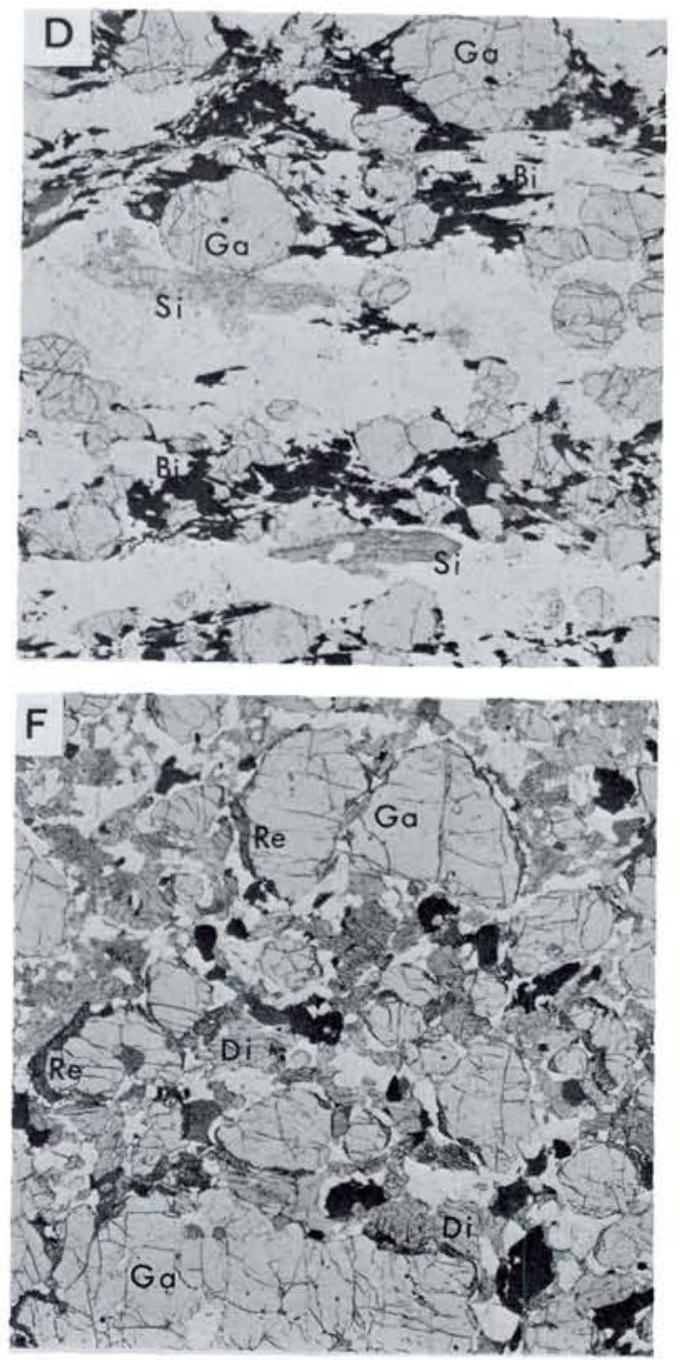
Fig. 4. View of the marginal granulites (s.s.) exposed at the south-western cliff face of nunatak 1600 . Note the well-bedded nature of these rocks. A peneplain like plateau between 1400 and $1600 \mathrm{~m}$ altitude can be seen in upper part of the picture.

apparent banded or well-bedded nature of these rocks, easily seen from a distance, arises from strong shearing and deformation of the rocks, rather than being a primary structure. Clear evidence for this is found in a swarm of steeply inclined magnetite-rich pegmatites which have been strongly deformed with the surrounding granulites. The magnetite has been sheared out to form layers parrallel to the foliation of the host-rock. Some poor striations within the magnetite layers suggests $\mathrm{E}-\mathrm{W}$ movements.

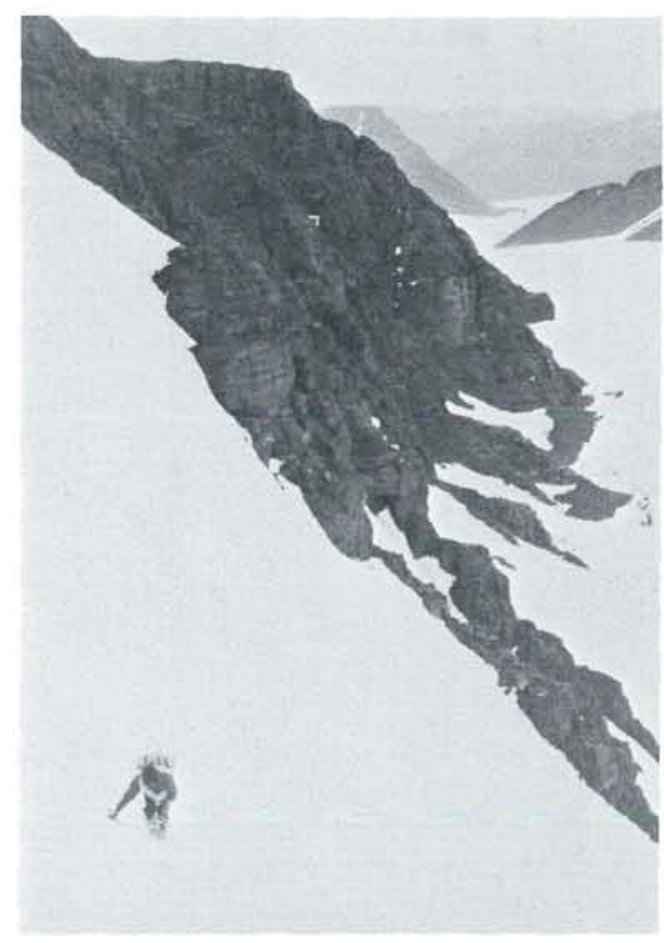

The granulites are fine grained, sometimes medium grained, massive rocks of grey to very dark grey colour. They are very fresh, but nevertheless carry the rusty brown weathering surface characteristic for hypersthene gneisses. Inspection of thin sections (fig. 3, sample 132906) reveals the presence of variable amounts of antiperthite, perthite, quartz, biotite, hypersthene, clinopyroxene, amphibole and opaque minerals (mainly magnetite). Relict garnet and apatite occur as accessory minerals.

Fig. 3. Thin sections $(10 \times)$ of six selected rock types from north-west Payers Land. A: Hypersthene gneiss from central gneiss complex (132924). Hypersthene (Hy), biotite ( $\mathrm{Bi})$ and magnetite/ilmenite (dark opaque) in a light groundmass of orthoclase/perthite and quartz. B: Metadolerite (132926) from central gneiss comlex. Garnet (Ga), diopside (Di) and magnetite/ilmenite (dark opaque) in a matrix of plagioclase/antiperthite. Note the exsolution lamaellae (ore?) along parting planes within the diopside. C: Granulite (s.s.) from marginal part of the gneiss complex (132906). Elongated, lensoid accumulations of quarts (Q) causes a laminated structure arising from combined ruptural and metamorphic deformation. The feldspar shows strong perthitic/antiperthitic structures (some indicated by arrows). The dark groundmass comprise biotite, amphibole, clinopyroxene, and small amounts of hypersthene and Fe-Ti oxides. Apatite occurs as a frequent, accessory mineral. $\times$ N. D: Garnet-biotite-sillimanite schist from the supracrustal rock sequence (132927). Garnet ( $\mathrm{Ga}$ ), biotite (Bi) and sillimanite ( $\mathrm{Si}$ ) in a light matrix of quartz and orthoclase/perthite. Some rare relicts of kyanite also occur (not shown). E: The same type rock type as above (D) deformed into a high grade mylonite close to a major metabasic body (132929). Rounded garnets (Ga) and some few old sillimanite grains ( $\mathrm{Si}$ ) in a groundmass of fine grained quartz, orthoclase, biotite and sillimanite. Most of the fine, grey material are newly formed sillimanite. $\times$ N. $F$ : Eclogite-like garnet-clinopyroxene rock (132931) from a major metabasic body at Nunatak 1800 (see also fig 2,6). Almandine - grossular - pyrope garnet (Ga) with a reaction rim (Re) of plagioclase, orthopyroxene and opaque material. See text for further details. Diopside (Di) and occasionally amphibole ranging from light to dark grey due to pleochroism. Plagioclase and quartz forms the intergranular material. Sphene and Fe-Ti oxides occur as accessory minerals. 


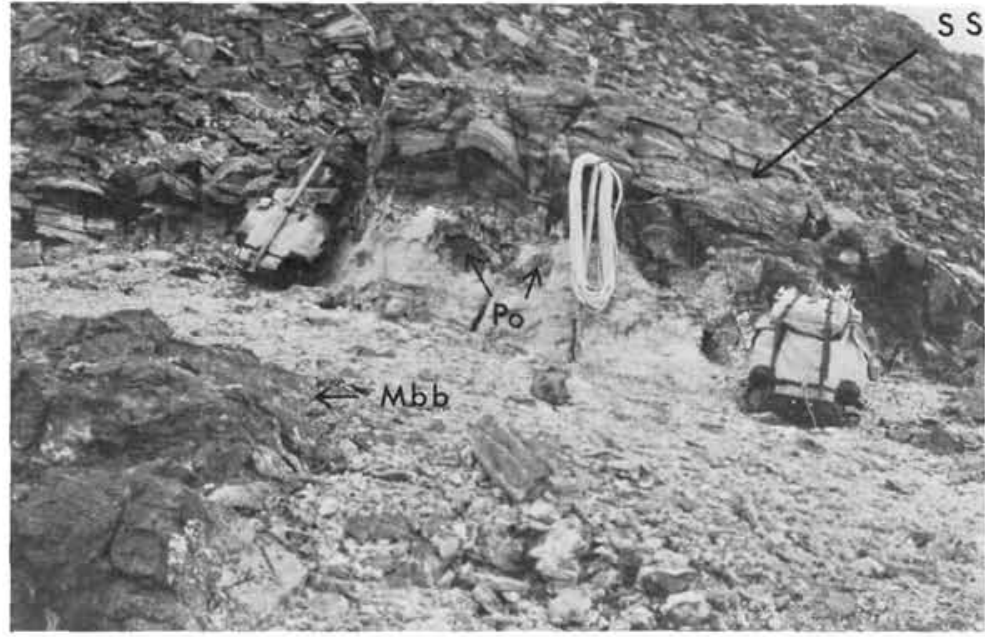

Fig. 5. Loose alteration products formed along the contact between a relative small (approx. $10 \times 20$ $\mathrm{m})$ metabasic boudin (Mbb) and the surrounding sillimanite schists (s.s.). Relative frech pods of metabasic material occur close to the schists (Po) which shows that deformation mainly took place within the competent material. However, where major competent bodies are present, the less competent schists has been deformed into high grade mylonites (see fig. 3, sample 132929 and fig. 6),
Modes of the granulites (s.s.) indicate a range from quartz-monzonite to leucogabbro in composition. Chemically they show a wide range from acid to basic composition, the most basic rock having a notably high alumina content (table 1, samples 132904, 132906 and 132918).

The marginal granulites are no doubt related to the dome-like central gneiss complex, but they appear to have a different origin. Whereas the nebulitic and partly agmatitic structures within the grey gneiss of the central gneiss complex reveal the existence of gneissic rocks prior to the latest deformation and metamorphism, the marginal granulites show no sign of relict structures. The textures of the granulites may correspond to those of strongly deformed plutonic rocks. However, the dominant presence of twinless feldspars with strong perthitic and/or antiperthitic structures indicates strong metamorphic recrystallization of these rocks, and any pre-existing structures may have been totally destroyed.

\section{Thrust zone}

The granulites and the overlying supracrystals are separated at nunatak 1600 by a few metre thick, prominent mylonite zone dipping $20^{\circ}-30^{\circ}$ to the NE. The mylonite itself consists of dark, fine to very fine grained, sometimes almost flinty rock, with porphyroclasts of clinopyroxene and feldspar, 1-4 mm across, in a groundmass of mainly feldspar and quartz. There is clear evi- dence for simultaneous metamorphic recrystallization and deformation, and no evidence of low-grade retrograde metamorphism.

\section{Supracrustal rocks}

A supracrustal sequence about $1000 \mathrm{~m}$ thick was examined at nunatak 1600 and nunatak 1800 (fig. 2 and 6). The sequence comprises gneissic schists and metabasic rocks, partly of eclogitic affinity. No pegmatites comparable to those within the granulites have been observed.

Schists. These are medium to coarse grained, biotite-garnet-sillimanite schists of semipelitic to pelitic composition (table 1, sample 132927). The invariable absence of muscovite and the presence of coexisting orthoclase (perthite) and abundant sillimanite clearly places the metamorphic grade of these rocks within the highest amphibolite facies. Except for some rare relicts of kyanite, the schists are of one facies, and show no sign of later retrograde metamorphism. In spite of the high metamorphic facies, only incipient and rather limited migmatisation has taken place.

Metabasic rocks. Metabasic bodies occur frequently within the supracrustal sequence as massive, thick units parallel to the foliation. These sheets of basic material show strong boudinage, and may be found as lines of basic pods. A rim of extremely deformed rocks ranging from loose 


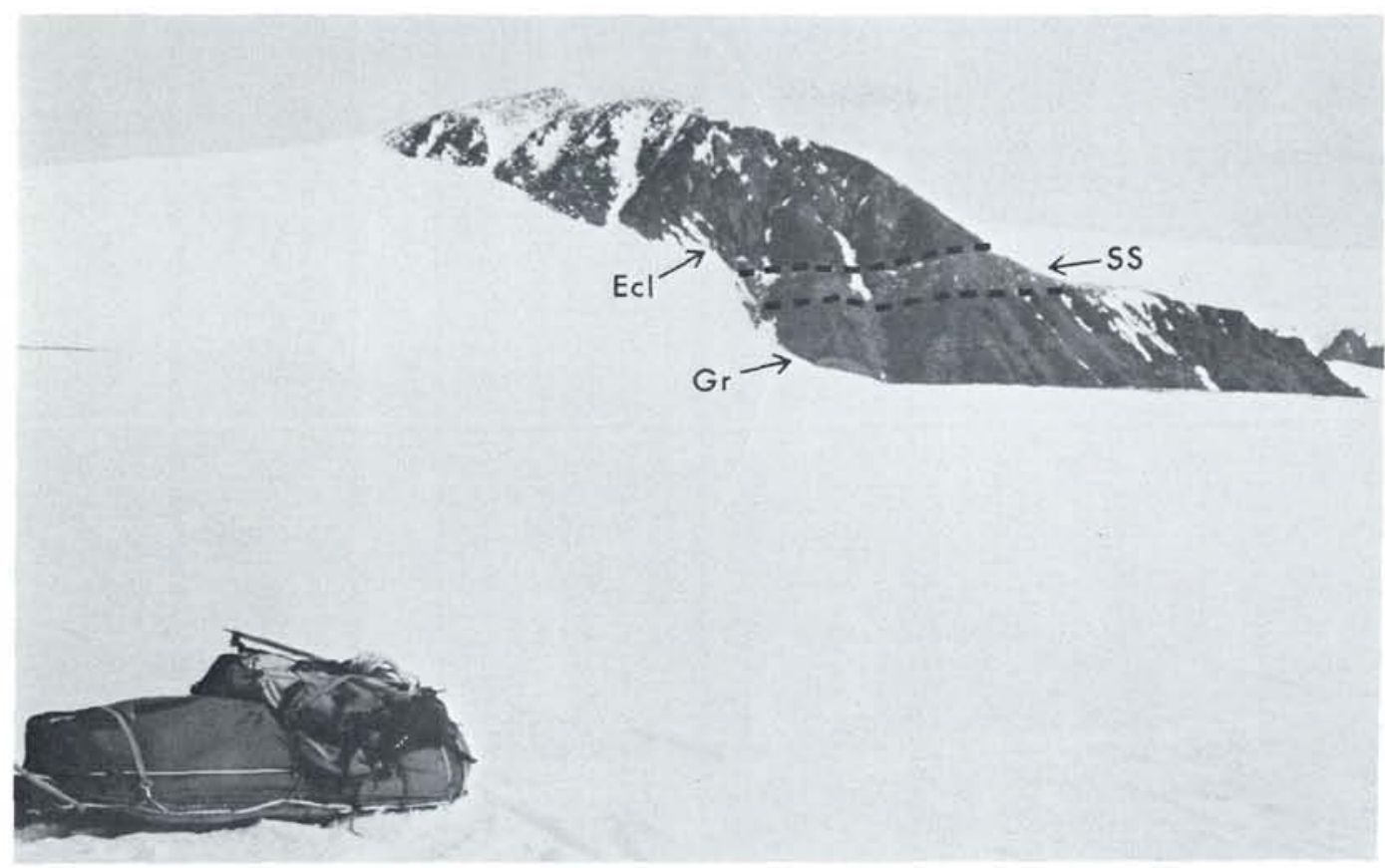

Fig. 6. View from west of nunatak 1800. Exposed cliff face about $500 \mathrm{~m}$ high. Granulites (Gr) exposed in the lower part, overlain by pelitic sillimanite schists (SS), and high grade mylonites close to the major eclogite-like metabasic body (Ecl) forming the top of the mountain. Sample 132927 (SS), 132929 and 132931 (Ecl) arises from this locality. See also fig. 2, 3 and 5.

alteration products to high grade mylonites, in most cases forms the sharp boundary between the metabasic bodies and the surrounding schists (fig. 3, sample 132927, fig. 5).

The basic rocks in general are medium to coarse-grained garnet-pyroxene-amphibolites, garnet-amphibolites or more rarely garnet-biotite-amphibolites. The feldspar content is generally low, in some cases nearly zero. Apart from some weak layering, which could be the remmants of an original magmatic layering, no evidence for the mode of origin was observed. Otherwise they appear as rather homogeneous rocks, totally recrystallized within the same facies and during the same metamorphic event as the surrounding pelitic rocks. No migmatisation was observed.

Emplacement of the basic material into the pelitic rocks is believed to have taken place prior to thrusting of the supracrustal sequence into its present position. The zone of strong deformation around the basic bodies is thought to have formed simultaneously with the main thrusting, and to have arisen from strong differential stress due to the relatively higher competence of the basic rocks.

Eclogite-like rocks. A major metabasic body, approximately $0.5 \mathrm{~km}^{3}$ in size occupies the north-west part of nunatak 1800 (fig. 2 and fig. 6). It is a medium to coarse grained, dark green rock, with prominent porphyroblasts of red to reddish-brown garnet up to $5 \mathrm{~cm}$ in diameter in a matrix of clinopyroxene.

Samples from central parts of this body have a distinct eclogite-like appearance. Verification of such extreme metamorphic conditions is of special interest as such rocks have not previously been reported from the region, and as a specific geotectonic setting (plate suture) is normally associated with their occurrence. Therefore a more detailed examination of this rock is presented below.

Chemically, this rock resembles ocean floor tholeiites with low concentrations of titanium, phosphor and potassium (table 1, sample 
TABLE 2

CIPW norms of two high grade metabasic rocks, north-west Payers Land

\begin{tabular}{cccccccccc}
\hline Sample no. & Q & OR & AB & AN & DI & HY & MT & IL & AP \\
132926 & 1.19 & 1.71 & 27.00 & 31.70 & 19.56 & 5.92 & 9.67 & 1.83 & 1.42 \\
132931 & 2.35 & 0.27 & 11.19 & 44.75 & 23.51 & 11.88 & 1.14 & 4.72 & 0.19 \\
\hline
\end{tabular}

132931). The CIPW norm indicates a quartznormative basaltic composition (table 2 , sample 132931), which differs considerably from the actual mode (fig. 3 ). The latter shows about equal amounts of colourless to faint green, pleochroic clinopyroxene, and pink garnet. Feldspar only occupies $5-10 \%$, invariable as interstitial reverse zoned plagioclase $\left(\mathrm{An}_{40}-\mathrm{An}_{50}\right)$. Quartz occupies about $5 \%$ of the matrix, and sphene, apatite and FeTi-oxides occur as accessory minerals. Clinopyroxene occurs as fresh, but irregular grains, whereas the rounded grains of garnet frequently show alteration at the rim.

Microprobe data, x-ray diffraction and emission spectral analysis show the presence of an almandine-grossular-pyrope garnet and the presence of nearly pure diopside with a small CaTs-content (Alm 57, Gross 23, Py 19, Spess 01 and Di 93, CaTs 07, table 3, sample 132931).

The alteration process of garnet can be summarized as follows:

Orthopyroxene + anorthite + ore $\rightleftarrows$ garnet + quartz

This process explains the formation of interstitial reverse zoned plagioclase by adding anorthite to a pre-existing albite-rich feldspar and is estimated to account for about half part of the feldspar present (fig. 3, sample 132931).
Green and Ringwood (1967) show that subsequent to garnet formation at the expense of orthopyroxene and anorthite, the final stage of the basalt-to-eclogite transition is characterized by formation of jadeite-rich diopside ("omphacite") and related break-down of albite, leading to a more or less feldspar-free mode depending on the bulk chemistry. Designation of the metabasic body of nunatak 1800 as "eclogite s.s." is, accordingly, not precluded by the presence of small amount of feldspar, but by the complete absence of jadeite within the diopside.

The possibility exists, however, that the pure diopside results from retrograde alteration of omphacite to diopside and albite. Some evidence for this is seen from the following: (1) the texture of the rock with exclusively interstitial feldspar; (2) one less eclogite-like metabasic rock from the central gneiss complex contains jadeite within the cores of clinopyroxene (tables 1, 2 and 3, sample 132926), which indicates that at least incipient omphacite formation conditions were reached in the region; (3) estimates of temperature-pressure conditions, based on Fe-Mg partition between garnet and clinopyroxene compared with the CaTs-content in clinopyroxene and co-existing plagioclase, indicate that eclogite formation conditions were reached $\left(12 \mathrm{~kb}, 740^{\circ} \mathrm{C}\right.$, table 3 , fig. 7 and E. Krogh, pers. comm. 1977).

TABLE 3

Results of microprobe analyses, X-ray diffraction and optical emission spectral analyses of garnet and clinopyroxene from two high grade metabasic rocks, north-west Payers Land

\begin{tabular}{cccc}
\hline Sample no. & Cpx-core & Cpx-rim & Garnet (very weak zonation) \\
132926 & Di92,Cats04,Jd04 & Di91,Cats09 & Alm57,Py20,Gross19, Spess02, And02 \\
132931 & Di94,Cats06 & Di93,Cats07 & Alm57,Gross23,Py19, Spess01 \\
\hline
\end{tabular}




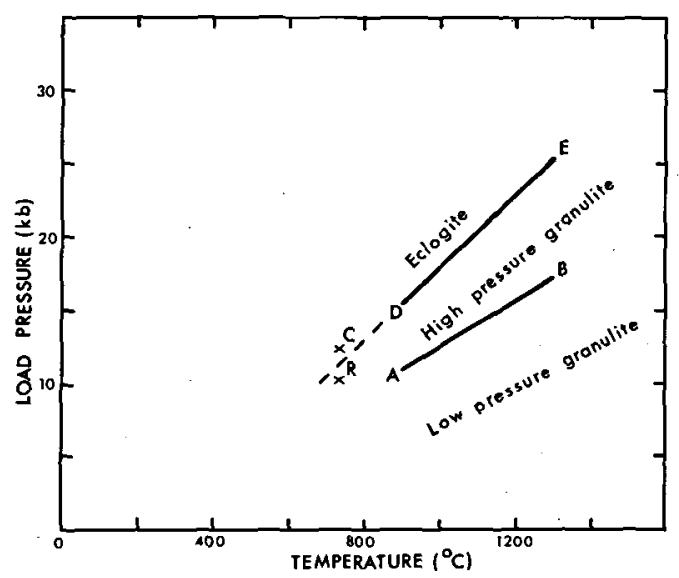

Fig. 7. Temperature - pressure diagramme showing experimental determined boundaries for first appearence of garnet $(A B)$ and disappearence of plagioclase (DE) in quartz tholeiitic basalts. Note that P-T estimates from core $\left(x^{\mathrm{C}}\right)$ and rim $\left(x^{\mathrm{T}}\right)$ of clinopyroxene in sample 132931 plots on either side of the straight extension of line $\mathrm{CD}$. See text (eclogite-like rocks and table 3 ) for further discussion. Experimental data from Green and Ringwood (1967).

\section{Discussion and conclusion}

\section{Source of magnetic anomalies}

The regional magnetic anomaly high of north-west Payers Land is clearly related to the presence of a high pressure, granulite facies, dome-like, gneiss-granulite complex. The central, high-frequency, anomaly area (fig. 2) correlates with surface exposures of this complex, and the individual anomalies relate to lithological differences and topography (fig. 2). The relatively higher concentration of magnetite and ilmenite within the granulite facies rocks, compared to the amphibolite facies supracrustal rocks, is not related to whole rock chemistry (table 1), but stems from the rock-forming position of the oxides within granulite facies at the expense of hornblende and biotite. The eclogite-like rocks are, however, exceptions. During the latest stages of this extreme alteration, iron is absorbed within garnets formed at the cost of orthopyroxene and magnetite, and, accordingly, the total magnetization of the rock is lowered considerably.
Metamorphism and geotectonic setting

The metamorphic facies exhibited by the central gneiss complex, the overlying supracrustal sequence, and the associated shear-zones, can be attributed to one common metamorphic event. The different facies conditions which occur, are only variations within a rather limited metamorphic range. Small gradients in temperature and pressure may play a role, but the content of water and other volatiles prior to metamorphism are thought to be the most important. Granulite facies conditions thus evolved within the rocks which already possessed a gneissic or plutonic structure (central gneiss complex and marginal granulites), whereas highest amphibolite facies conditions evolved within the supracrustal pelitic rocks. The nature of metabasic rocks from the central gneiss complex and from the supracrustal sequence show that high pressure granulite facies to eclogite conditions were reached with load-pressures not less than 10-12 kb and temperatures well above $700^{\circ}$ (fig. 7).

Low grade retrograde metamorphic alterations are not seen in any of the rocks units examined, including shear and thrust zones. A decreasing pressure/temperature ratio during metamorphism is, however, indicated by the zoning of clinopyroxene in the basic rocks of the central gneiss complex, by zoning and/or alteration of garnet and feldspar in metabasic rocks from the supracrustals, and by the rare relicts of kyanite in sillimanite-bearing pelitic schists. Estimates of pressure and temperature conditions (fig. 7) indicate that this ratio was lowered mainly due to release of pressure. The main movements and associated shearing ceased, while high temperature conditions including sillimanite formation still prevailed. The verification of the extreme conditions implied by the occurrence of eclogite-like rocks is of particular interest, as they are normally of restricted extent and are believed to be diagnostic for Benioff-zone environments (i.e. nearby plate-suture). The complex studied here could, as a preliminary hypothesis, be viewed as a segment of crust deformed at a deep level near a subduction zone (kyanite and eclogite formation), and later transferred to a different position with a higher temperature/pressure ratio (sillimanite formation and regression of eclogites). The juxtaposition of high alumina basaltic/andesitic rocks and ocean floor type tholeiites (table 
1, sample 132918 and 132931) could be explained by this model, the two types coming together at a destructive plate boundary.

\section{Regional setting}

The rock types and metamorphic conditions found in north-west Payers Land are remarkable, as such facies have not been reported elsewhere from the East Greenland fold belt, with the possible exception of south-western Liverpool Land (Kranck 1935, Haller 1971, Higgins et al. 1977). They appear incompatible with the geological interpretation of Koch and Haller (1971) and Haller (1971), who viewed Payers Land as part of the Caledonian fold belt, and indicated the presence of synorogenic Caledonian granites and gneissic migmatites within the central gneiss complex, overlain by biotite schists and amphibolites. The contact between the migmatites and the schists was believed to represent a. regional migmatite front, i.e. to be thermodynamically controlled rather than of tectonic origin. The "biotite schists" of Koch and Haller (1971) (= pelitic schists in this study) were presumed to be the metamorphic equivalents of the late Precambrian Eleonore Bay Group.

The new observations from north-west Payers Land differ from the views of Haller (1970, 1971) and Koch and Haller (1971) in the following: (1) nebulitic and locally agmatitic structures are far more important within the central gneiss complex than the postulated 'migmatitic' structures, and no granites were observed in the area; (2) the contact between the gneiss and overlying supracrustals was found to be of tectonic origin; (3) the metamorphic facies and structures recorded are considered not to be due to Caledonian metamorphic events, partly because of their nature, and partly because non-metamorphic late Precambrian and Cambro-Ordovician sediments outcrop only 10-20 $\mathrm{km}$ to the south-east (fig. 2, Koch and Haller 1971, Haller 1970).

Attempts to date the gneisses of north-west Payers Land isotopically have not been successful due to the limited amount of material available, and very low $\mathrm{Rb} / \mathrm{Sr}$ ratios. Some indication of possible age can, however, be deduced from comparisons with other parts of the East Greenland fold belt.

Considerable geological and isotopic work has been carried out in the southern part of the East Greenland fold belt during the past decade (summary in Higgins and Phillips 1979, and Steiger et al. 1979). The major regions of crystalline infracrustal rocks suggested by Haller (1971) to be of Caledonian origin, have been shown to retain evidence of a Precambrian evolution. Archaean, Svecofennian (Hudsonian) and Grenvillian isotopic ages have been obtained from gneiss complexes and granites. Many of the widespread supracrustal sequences once thought to have represented metamorphosed parts of the Late Precambrian Eleonore Bay Group, appear to have suffered a significant metamorphic episode in pre-Caledonian time. These widespread psammitic and pelitic developments (the Krummedal supracrustal sequence and presumed equivalents between $70^{\circ}-73^{\circ} \mathrm{N}$, Higgins 1974) have yielded middle Proterozoic isotopic ages. A more localised sequence including volcanics and gabbroic rock types in the Charcot Land area $\left(72^{\circ} \mathrm{N}\right)$ has given early Proterozoic ages. (Hansen et al. in press).

The central gneiss complex of north-west Payers Land compares most closely with the infracrustal gneiss complexes of regions to the south, and an Archaean, or possibly early Proterozoic, age of formation seems most probable. The frequent occurrence of metabasic rocks within the overlying supracrustal rocks suggests, perhaps, closer comparison with the Charcot Land supracrustal sequence than with the Krummedal supracrustal sequence or its equivalents.

The wider presence of similar magnetic anomaly areas within the East Greenland fold belt can, of course, only be used in a very indirect way in the search for other pre-Caledonian crystalline units. The method has, however, also been applied to the Norwegian Caledonides with fairly conclusive results ( $\AA \mathrm{m}$ 1975).

Areas between $70^{\circ} \mathrm{N}$ and $76^{\circ} \mathrm{N}$ comprising magnetic anomaly populations which may be indicative of the presence of pre-Caledonian crystalline units are shown in fig. 1. Among these areas, area A correlates well with the Hinks Land gneiss and schist complex and its northward continuation into Gletscherland, the whole region believed to be of Archaean to early Proterozoic origin (Henriksen \& Higgins 1976, Higgins \& Phillips 1979). Area B also corresponds to pre- 
sumed Proterozoic rocks of the Liverpool Land crystalline complex (Henriksen \& Higgins 1976, Coe and Cheeney 1971). Details for area C, D and $E$ are not known, but they can tentatively be assumed to comprise material of similar origin to that of the north-west Payers Land rocks.

It thus seems likely that most magnetic anomaly populations within the East Greenland fold belt relate to more or less reworked units of $\mathrm{Ar}$ chaean to early Proterozoic gneisses and schists, whereas middle and late Proterozoic migmatites and schists, and the areas of Caledonian origin, are almost non-magnetic.

Acknowledgements. Thanks are expressed to Niels Dahl Knudsen for valuable field geological guidance and assistance. The aeromagnetic survey and the field work were funded by the Geological Survey of Greenland and made possible by the combined efforts of $\mathrm{N}$. Henriksen and B. Leth Nielsen. Major element analyses were carried out by I. Sørensen, GGU Chemical Laboratory. Trace element chemistry was undertaken by $\mathbf{J}$. Bailey and emission spectral analyses on garnets were made by H. Bollingberg, both Institute of Petrology, University of Copenhagen. X-ray diffraction determinations were made by $\mathbf{E}$. Leonardsen, Institute of Mineralogy, University of Copenhagen. Microprobe analyses and temperature-pressure estimates were kindly made available by E. Krogh, formerly Oslo University, now at University of Tromsø. H. Zeck, J. Engel and $I$. Bryhni made valuable suggestions for the interpretation of thin sections. A. K. Higgins and N. Springer reviewed the manuscript and made valuable suggestions, most of which have been adapted. The paper is published with the permission of the Director of The Geological Survey of Greenland.

\section{Dansk sammendrag}

Aeromagnetiske, geologiske og geokemiske data viser tilstedeværelsen af et højtryks granulitfacies gnejskompleks indenfor et tidligere næsten helt uundersøgt nunatakområde mellem $74^{\circ} 30^{\prime}$ og $75^{\circ} \mathrm{N}$ i Nordøstgrønland. Gnejskomplekset er omgivet af, og delvis dækket af, overskudte suprakrustale bjergarter metamorfoseret under hojeste amfibolitfacies. Eklogitlignende granat-clinopyroxen bjergarter forekommer indenfor suprakrustalserien. Det magnetiske billede består af et centralt, højamplitude, højfrekvent anomali område $i$ nær tilknytning til blotninger af granulitfacies bjergarter, hvorimod de omgivende suprakrustalbjergarter giver anledning til en magnetisk rolig zone. Feltrelationer, mineralparageneser, mineralreaktioner samt fordelingen af bestemte elementer indikerer at granulitfaciesmetamorfosen og højeste amfibolitfaciesmetamorfosen begge stammer fra samme metamorfe hændelse med en maksimum temperatur på lidt over $700^{\circ} \mathrm{C} \mathrm{og} \mathrm{maksimum} \mathrm{tryk} \mathrm{omkring}$ eller lidt over $12 \mathrm{~kb}$ (kyanit dannelse), senere aftagende til omkring $10 \mathrm{~kb}$ (sillimanit dannelse). Sammenligninger med andre dele af den østgrønlandske foldekæde tyder pá en gammel, Arkæisk alder for det centrale gnejskompleks og en tidlig Proterozoisk alder for granulit/amfibolit facies metamorfosen. Det undersøgte område udviser ikke tegn på senere (kaledoniske) metamorfe hændelser i modsætning til den tidligere foreslåede kaledoniske oprindelse.

\section{References}

Buddington, A. F. 1939: Adirondack Igneous Rocks and their Metamorphism. Geol. Soc. Am. Mem. 7, 353 pp.

Coe, K. and Cheeney, R. F. 1971: Preliminary results of mapping in Liverpool Land, East Greenland. Rapp. Gronlands geol. Unders. 48, 7-19.

Green, D. H. \& Ringwood, A. E. 1967: An experimental investigation of the gabbro to eclogite transformation and its petrological applications. Geochim. Cosmochim. Acta 31, 767-838.

Haller, J. 1970: Tectonic map of East Greenland (1:500,000). An account of tectonism, plutonism, and volcanism in East Greenland. Meddr Gronland 171,5, 286 pp.

Haller, J. 1971: Geology of the East Greenland Caledonides. Interscience Publishers, New York, 413 pp.

Hansen, B. T., Steiger, R. H. and Higgins, A. K. 1980: Isotopic evidence for a Precambrian metamorphic event within the Charcot Land window, East Greenland Caledonian fold belt. Bull. geol. Soc. Denmark, 29: 151-160.

Henriksen, N. \& Higgins, A. K. 1976: East Greenland Caledonian fold belt. In Escher, A. and Watt, W. S. (edit.) Geology of Greenland, 182-246 Copenhagen: Geol. Surv. Greenland.

Higgins, A. K. 1974: The Krummedal supracrustal sequence around inner Nordvestfjord. Scoresby Sund, East Greenland. Rapp. Grønlands geol. Unders. 67, 34 pp.

Higgins, A. K., Friderichsen, J. D. and Thyrsted, T. 1977: Basement-cover relationships and metamorphic studies in the East Greenland Caledonides $\left(72^{\circ}-74^{\circ} \mathrm{N}\right)$. Rapp. Gronlands geol. Unders. 85, 109-113.

Higgins, A. K. and Philips, W. E. A. 1979: East Greenland Caledonides - an extension of the British Caledonides. In Holland, C. H. \& Leake, B. E. (edit.) The Caledonides of the British Isles - reviewed. Geol. Soc. London, Spec. Publ. 8, 19-32.

Koch, L. \& Haller, J. 1971: Geological map of East Greenland $72^{\circ}-76^{\circ} \mathrm{N}$. Lat. $(1: 250,000)$. Meddr Gronland $183,26 \mathrm{pp}$.

Kranck, E. H. 1935: On the crystalline complex of Liverpool Land. Meddr Gronland 97,7: 122 pp.

Larsen, H. C. 1975a: Aeromagnetic investigations in East Greenland. Rapp. Gronlands geol. Unders. 75, 88-91.

Larsen, H. C. 1977: Aeromagnetiske undersøgelser $i \emptyset_{\text {st- }}$ grønland 1974 (in Danish). Unpublished internal report in open GGU-file. 124 pp.

Leedal, G. P. 1952: The crystalline rocks of East Greenland between latitudes $74^{\circ} 30^{\prime}$ and $75^{\circ} \mathrm{N}$. Meddr Gronland $142,6,80 \mathrm{pp}$.

Mittelholzer, A. E. 1941: Die Kristallingebiete von Clavering- $\emptyset$ und Payer Land (Ostgrønland). Meddr Grønland $114,8,42$ pp.

Nielsen, B. L. \& Larsen, H. C. 1974: Airborne geophysical survey in central East Greenland. Rapp. Gronlands geol. Unders. 55, 73-76.

Nielsen, B. L. \& Steenfelt, A. 1975: Prospecting for uranium in central East Greenland. Rapp. Grønlands geol. Unders. $75,107-110$.

Quensel, P. 1952: Charnockite series of the Varberg district on the southwestem coast of Sweden. Arkiv Min. Geol. 1, 227-332.

Steiger, R. H., Hansen, B. T., Schuler, C., Bär, M. T. \& Henriksen, N. 1979: Isotopic age determination revealing the polyorogenic nature of the southern Caledonian Fold Belt in East Greenland. Jl. Geology 87, 475-495.

Taylor, S. R. 1965: The application of trace element data to problems in petrology In Physics and chemistry of the earth, 6: 133-213.

Waard, E. de 1965: A proposed subdivision of the granulite facies. Am. J. Sci. 263, 455-461. 
Waard, D. de 1967: Precambrien geology of the Adirondack highlands, a reinterpretation. Geol. Rundschau 56, 596-629.

Winkler, H. G. F. 1967: Die Genese der metamorphen Gesteine. Springer Verlag, Berlin. 233 pp.

Ám, K. 1975: Aeromagnetic Basement Complex Mapping North of Latitude $62^{\circ} \mathrm{N}$, Norway. Norges geol. Unders. 316, 351-374. 